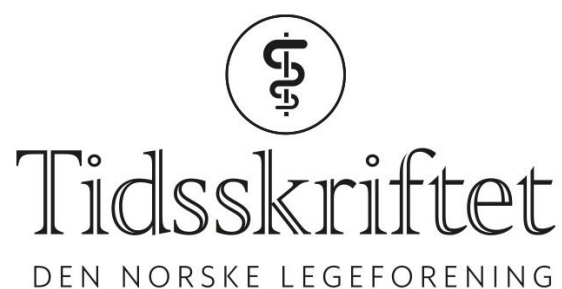

DEN NORSKE LEGEFORENING

\title{
Nils Raknerud
}

MINNEORD

JAN IVAR PEDERSEN

STEINAR AASE

Vår gode venn og kollega Nils Raknerud døde 3o. juli etter mange års plager med Parkinsons sykdom. Han ble 80 år gammel.

Nils sin vennlige, beskjedne og sympatiske væremåte manifesterte seg allerede tidlig i studietiden. Kullkamerater ble flere ganger invitert til hans foreldres vakre hjem på Nordberg. De av oss som kom fra Utkant-Norge satte spesielt stor pris på det. Nils beskjeftiget seg med mye mer enn det medisinskfaglige. Hans interesse for fransk språk og kultur gjorde at en av oss fikk spesielt god kontakt med ham. Han og Inger var medlemmer av foreningen Souvenir Normand, og gjennom denne ble det mange fine turer og opplevelser i Frankrike.

Nils var belest og engasjert også på en rekke andre felt. Han hadde kunnskaper i historie, politikk, kunst og økonomi. En samtale med ham var alltid spennende og interessant.

Nils tok medisinsk embetseksamen i 1962. Han begynte spesialisering i patologi på Rikshospitalet i 1969, og ble tildelt medisinsk doktorgrad i 1978 på grunnlag av en elektronmikroskopisk studie av hud. Han ble overlege i patologi ved Aker sykehus i 1976 og jobbet fra 1987 til pensjonsalder som avdelingsoverlege.

På Aker fortsatte han med elektronmikroskopi og forskning, men det meste av tiden måtte nå gå til diagnostisk patologi. Nils var allsidig i diagnostikken av vevsprøver og særlig kunnskapsrik når det gjaldt leversykdommer. I hele sin yrkeskarriere opprettholdt han et betydelig engasjement for obduksjonspatologi, og sørget for at avdelingen på Aker sykehus hadde høy kompetanse på dette tradisjonsrike feltet. Nils Raknerud hadde bred kompetanse som patolog, helt fra de minste elektronmikroskopiske detaljer og til den makroskopiske diagnostikken ved obduksjoner. Han la stor vekt på å formidle funn og resultater til kolleger. Han viste stor interesse for rekruttering og opplæring av nye patologer, og var en dyktig og vennlig veileder.

Nils traff sin Inger i relativt moden alder. Hun ble en trofast og god støtte for ham. De holdt sitt hus åpent for familie og venner, og samværet med dem var alltid en givende opplevelse.

Vi føler nå med Inger og den øvrige familie. 
(ㅇ) Tidsskrift for Den norske legeforening 2020. Lastet ned fra tidsskriftet.no 